\title{
Analisis Pemahaman Nilai-Nilai Karakter dalam Pembelajaran Bahasa Indonesia Melalui Bermain Peran di Kelas II
}

\section{Nurulita Anisa Amalia ${ }^{1 *}$, Ikha Listyarini ${ }^{2}$, Muhammad Arief Budiman ${ }^{3}$}

123 Universitas PGRI Semarang, Semarang, Indonesia

*e-mail: anisaamal75@gmail.com

\begin{abstract}
Abstrak
Penelitian ini dilatarbelakangi oleh kurang maksimalnya pendidikan karakter sehingga berdampak pada sikap siswa yang kurang baik. Penelitian ini bertujuan untuk menganalisis pemahaman nilai-nilai karakter dalam pembelajaran bahasa indonesia melalui bermain peran di kelas II. Penelitian ini termasuk penelitian studi kasus dengan metode penelitian yang berlandaskan pada filsafat postpositivisme, digunakan untuk meneliti pada kondisi obyek yang alamiah. Metode pengumpulan data menggunakan observasi, dokumentasi dan wawancara. Teknik analisis data pada penelitian ini adalah teknik analisis data statistik kualitatif menggunakan teknik keabsahan data menggunakan trianggulasi berupa pengumpulan data, seleksi data, menyajikan data dan penarikan kesimpulan. Hasil penellitian menunjukkan ada beberapa nilai-nilai karakter yang terintegrasi melalui permainan bermain peran yaitu nilai religius, nilai disiplin, nilai jujur, nilai kerja keras, nilai kreatif, nilai mandiri, nilai rasa ingin tahu, nilai semangat kebangsaan, nilai bersahabat/komunikatif, nilai cinta damai, nilai gemar membaca, nilai peduli lingkungan, nilai peduli sosial, nilai demokratis, dan nilai tanggungjawab. Simpulan penelitian ini adalah melalui permaianan bermain peran terdapat nilai-nilai karakter yang terintegrasi didalamnya. Implikasi penelitian ini berdampak pada karakter siswa yang semakin baik dan kegiatan belajar menjadi lebih aktif karena siswa menyukai pembelajaran Bahasa Indonesia melalui bermain peran karena menciptakan suasana yang menyenangkan.
\end{abstract}

Kata kunci: karakter, bahasa indonesia, bermain peran

\begin{abstract}
This research was motivated by a lack of character education which resulted in poor student attitudes. This study aims to analyze the understanding of character values in Indonesian language learning through role-playing in class II. This research includes a case study research with a research method based on the philosophy of postpositivism, which is used to examine the conditions of natural objects. Methods of data collection using observation, documentation, and interviews. The data analysis technique in this study is a qualitative statistical data analysis technique using data validity techniques using triangulation in the form of data collection, data selection, presenting data, and drawing conclusions. The results of the research show that there are several integrated character values through role-playing, namely religious values, disciplinary values, honest values, hard work values, creative values, independent values, curiosity values, national spirit values, friendly/communicative values, values. love peace, values like reading, values caring for the environment, values social care, democratic values, and values responsibility. This research concludes that through role-playing games there are character values integrated with it. The implication of this research has an impact on the character of students who are getting better and learning activities become more active because students like learning Indonesian through role-playing because it creates a pleasant atmosphere.
\end{abstract}

Keywords: character, Indonesian, role-playing.

\footnotetext{
${ }^{*}$ Corresponding author.

Received 30 Januari 2021; Accepted 1 Maret 2021; Available online 8 April 2021 (C) 2021 MI All Rights Reserved
} 


\section{Pendahuluan}

Pendidikan karakter menjadi keharusan karena untuk meningkatkan mutu penyelenggaraan dan hasil pendidikan yang mengarah pada pencapaian pembentukan karakter dan akhlak yang mulia peserta didik secara utuh, terpadu dan seimbang (Maulida, M., Wati \& An'nur, 2015; Shafa, 2014; Widiatmaka, 2016). Melalui pendidikan karakter diharapkan peserta didik secara mandiri meningkatkan dan menggunakan pengetahuannya, mengkaji dan menginternalisasi, serta mempersonalisasi nilai-nilai karakter dan akhlak mulia sehingga terwujud dalam perilaku sehari-hari serta dalam lingkungan sekolah.

Dalam pelaksanaan pendidikan karakter di sekolah dapat di aplikasikan dengan mata pelajaran yang ada di sekolah, seperti mata pelajaran Bahasa Indonesia, mata pelajaran Indonesia sangat mempengaruhi Pendidikan Karakter di Sekolah. Terdapat 4 aspek berbahasa Indonesia, yaitu mendengarkan (menyimak), berbicara, membaca, dan menulis (Astuti, 2016; Dharmawan et al., 2014; Ramadhanti, 2015). Mendengarkan dan berbicara merupakan aspek keterampilan berbahasa ragam lisan, sedangkan membaca dan menulis merupakan kerampilan berbahasa ragam tulis. Mendengarkan dan membaca adalah keterampilan berbahasa yang bersifat reseptif, sedangkan berbicara dan menulis bersifat produktif. Untuk menguasai keempat jenis keterampilan berbahasa tersebut seseorang harus menguasai sejumlah ketrampilan mikro.

Pembelajaran Bahasa di SD sangat berpengaruh dengan pendidikan karakter. Dalam pembelajaran yang berlangsung menggunakan ketrampilan berbahasa dengan tujuan komunikasi dapat terjalin dengan baik, dalam terjalinnya komunikasi yang baik itu terjadi proses encoding ia terampil memilih bentuk-bentuk bahasa yang tepat, sesuai dengan konteks komunikasi (Indriyani et al., 2019; Puspidalia, 2012; Ramadan \& Mulyat, 2020),. Dalam proses komunikasi tersebut peserta didik akan memformulasikan secara tepat dengan menyampaikan rasa, karsa, pemikiran, gagasan dan perbuatan yang baik. Dalam proses komunikasi dalam pembelajaran Bahasa Indonesia dapat dilakukan dengan kegiatan berdialog.

Berdialog dapat diartikan sebagai pertukaran pikiran atau pendapat mengenai suatu topik tertentu antara 2 orang atau lebih, fungsi utama berdialog adalah bertukar pikiran, mencapai mufakat atau merundingkan suatu masalah (Musaffak, 2014; Sufanti et al., 2017; Yulia et al., 2019). Dialog dapat diwujudkan dalam berbagai bentuk, seperti bertelepon, bercakap-cakap, tanya-jawab, wawancara, diskusi, musyawarah (Budi Febriyanto, 2019; Kurniasari, 2017; Tisnasari, 2017). Sebuah pembelajaran yang didalamnya terdapat dialog menjadi menarik untuk dikolaborasikan dengan pendidikan karakter, tetepi sebuah Pendidikan karakter yang diterapkan di sekolah juga memerlukan sebuah metode.

Berdasarkan pengamatan yang sudah dilakukan oleh peneliti, bahwa di SDN Pandeanlamper 05 Semarang masih jarang dalam penggunaan metode bermain peran dalam pembelajaran, maka dari itu peneliti ingin menganalisis tentang nilai-nilai karakter yang muncul dalam bermain peran yang berhubungan dengan kurikulum 2013, karena nilai karakter pada saat ini masih belum terungkap dan belum dianalisa lebih lanjut, pendidikan karakter bagi anak SD dimaksudkan untuk menanamkan nilai-nilai kebaikan supaya dapat menjadi kebiasaan kelak dewasa atau pada jenjang selanjutnya. Peneliti mengambil tempat penelitian di SDN Pandeanlamper 05 Semarang. Dalam penelitian ini penulis ingin menggunakan metode bermain peran dan praktik langsung yang dapat meningkatkan perkembangan nilai-nilai pendidikan karakter anak dan diharapkan sekolah dapat mengkonsistenkan nilai karakter yang muncul saat bermain peran pada anak, sehingga anak mempunyai pengalaman hidup yang baik. Pendidikan karakter dapat membuat siswa menjadi seseorang yang tidak hanya cerdas aka tetapi juga memiliki moral yang baik sesuai dengan butir-butir Pancasila, hal tersebut bisa tercapai dengan metode bermain peran (Dharmawan et al., 2014; Wahyuni et al., 2016; Yulianto et al., 2020). 
Bermain peran adalah sebuah permainan yang para pemainnya memainkan sebuah permainan yang para pemainnya memainkan dan berkolaborasi untuk merajut sebuah cerita bersama (Dewi et al., 2017; Fitry et al., 2019; Oktivianto et al., 2018). Melalui metode pembelajaran bermain peran, anak dilatih untuk mengungkapkan ide, harapan, dan keinginan mereka sesuai imajinasi dengan batasan cerita atau peran yang diberikan (Ananda, 2018; Fatimah, 2015; Kristin, 2018). Metode bermain peran juga memberikan suasana baru bagi anak didik dalam proses pembelajaran yang dilakukan dalam suasana bermain tanpa terbebani oleh tugas perkembangannya. Kelebihan bermain peran menjadikan suasana suatu pembelajaran akan lebih menyenangkan sebab bermain peran dapat membantu memecahkan permasalahan sebelumnya bersifat abstrak menjadi masalah konkret setelah diperankan, melalui bermain peran ini mengajarkan berbagai ketrampilan seperti bersosialisasi, spontanitas dan kreativitas dengan cara memerankan suatu peran yang nyata dalam kehidupan sehari-hari siswa (Kristin, 2018; Oktivianto et al., 2018; Yulianto et al., 2020).

Berdasarkan berbagai pustaka tentang pentingnya pendidikan karakter di atas, penting kiranya bagi para pendidik untuk memiliki kemampuan khusus dalam menyisipkan pendidikan karakter dalam semua bidang studi yang diajarkannya di level pendidikan sekolah dasar. Hal ini karena pada level pendidikan sekolah dasar anak-anak masih rentan dalam pergaulan sehingga mereka masih mudah untuk dipengaruhi (Arwanda et al., 2020; Indriani, 2015; Raditya \& Iskandar, 2020). Tugas para guru lah untuk memberikan berbagai pengaruh yang positif terhadap para siswa tersebut. Penelitian ini didukung beberapa penelitian sebelumnya yaitu, pertama penelitian yang dilakukan oleh Labudasari \& Rochmah (2018) menyatakan bahwa gerakan literasi berpengaruh terhadap karakter mandiri siswa sekolah dasar. Kedua, penelitian yang dilakukan oleh Morelent \& Syofiani (2018), yang mendapatkan hasil penelitian bahwa penerapan kurikulum 2013 berpengaruh terhadap pembentukan karakter siswa sekolah dasar. Ketiga, penelitian yang dilakukan oleh Rosnawati et al., (2015) yang mendapatkan hasil penelitian bahwa model pembelajaran berbasis masalah bermain peran dapat meningkatkan rasa cinta tanah air siswa sekolah dasar.

Tujuan penelitian ini untuk menganalisis pemahaman nilai-nilai karakter dalam pembelajaran Bahasa Indonesia melalui bermain peran di kelas II SDN Pandeanlamper 05 Semarang. Diharapkan melalui penanaman nilai karakter melalui bermain peran pada mata pelajaran Bahasa Indonesia dapat meningkatkan karakter siswa kearah yang lebih baik.

\section{Metode}

Penelitian ini termasuk kedalam jenis penelitian yaitu penelitian studi kasus dengan metode penelitian yang berlandaskan pada filsafat postpositivisme, digunakan untuk meneliti pada kondisi obyek yang alamiah. Subjek penelitian ini adalah nilai-nilai karakter dalam pembelajaran Bahasa Indonesia melalui bermain peran. Penelitian ini dilaksanakan pada siswa kelas II di SDN Pandeanlamper 05 Semarang.

Metode pengumpulan data yang digunakan pada penelitian tentang nilai-nilai karakter dalam pembelajaran Bahasa Indonesia melalui bermain peran adalah metode pengumpulan data berupa observasi, dokumentasi dan wawancara. Teknik analisis data pada penelitian ini adalah teknik analisis data statistik kualitatif menggunakan teknik keabsahan data menggunakan trianggulasi berupa pengumpulan data, seleksi data, menyajikan data dan penarikan kesimpulan. Analisis data kualitatif adalah upaya yang dilakukan dengan jalan bekerja dengan data, mengorganisasikan data, memilah-milahnya menjadi satuan yang dapat dikelola, mensistematiskannya, mencari dan menemukan pola, menemukan apa yang penting dan apa yang dapat diceritakan kepada orang lain. (Ananda \& Fadhilaturrahmi, 2018; Dardiri et al., 2017; Liu, 2019). 


\section{Hasil dan Pembahasan}

Berdasarkan pengamatan yang sudah dilakukan oleh peneliti, bahwa di SDN Pandeanlamper 05 Semarang masih jarang dalam penggunaan metode bermain peran dalam pembelajaran, maka dari itu peneliti ingin menganalisis tentang nilai-nilai karakter yang muncul dalam bermain peran yang berhubungan dengan kurikulum 2013, karena nilai karakter pada saat ini masih belum terungkap dan belum dianalisa lebih lanjut, pendidikan karakter bagi anak SD dimaksudkan untuk menanamkan nilai-nilai kebaikan supaya dapat menjadi kebiasaan kelak dewasa atau pada jenjang selanjutnya. Peneliti mengambil tempat penelitian di SDN Pandeanlamper 05 Semarang. Dalam penelitian ini penulis ingin menggunakan metode bermain peran dan praktik langsung yang dapat meningkatkan perkembangan nilai-nilai pendidikan karakter anak dan diharapkan sekolah dapat mengkonsistenkan nilai karakter yang muncul saat bermain peran pada anak, sehingga anak mempunyai pengalaman hidup yang baik.

Dalam pelaksanaan pendidikan karakter di sekolah dapat di aplikasikan dengan mata pelajaran yang ada di sekolah, seperti mata pelajaran Bahasa Indonesia, mata pelajaran Indonesia sangat mempengaruhi Pendidikan Karakter di Sekolah. Terdapat 4 aspek berbahasa Indonesia, yaitu mendengarkan (menyimak), berbicara, membaca, dan menulis. Mendengarkan dan berbicara merupakan aspek keterampilan berbahasa ragam lisan, sedangkan membaca dan menulis merupakan kerampilan berbahasa ragam tulis (Astuti, 2016; Dharmawan et al., 2014; Ramadhanti, 2015). Mendengarkan dan membaca adalah keterampilan berbahasa yang bersifat reseptif, sedangkan berbicara dan menulis bersifat produktif. Untuk menguasai keempat jenis keterampilan berbahasa tersebut seseorang harus menguasai sejumlah ketrampilan mikro.

Pembelajaran Bahasa di SD sangat berpengaruh dengan pendidikan karakter, hal ini sesuai dengan pernyataan (Indriyani et al., 2019; Puspidalia, 2012; Ramadan \& Mulyat, 2020) bahwa dalam pembelajaran yang berlangsung menggunakan ketrampilan berbahasa dengan tujuan komunikasi dapat terjalin dengan baik, dalam terjalinnya komunikasi yang baik itu terjadi proses encoding ia terampil memilih bentuk-bentuk bahasa yang tepat, sesuai dengan konteks komunikasi. Dalam proses komunikasi tersebut peserta didik akan memformulasikan secara tepat dengan menyampaikan rasa, karsa, pemikiran, gagasan dan perbuatan yang baik. Dalam proses komunikasi dalam pembelajaran Bahasa Indonesia dapat dilakukan dengan kegiatan berdialog. Pendidikan karakter dapat membuat siswa menjadi seseorang yang tidak hanya cerdas aka tetapi juga memiliki moral yang baik sesuai dengan butir-butir Pancasila, hal tersebut bisa tercapai dengan metode bermain peran (Dharmawan et al., 2014; Wahyuni et al., 2016; Yulianto et al., 2020).

Bermain peran adalah sebuah permainan yang para pemainnya memainkan sebuah permainan yang para pemainnya memainkan dan berkolaborasi untuk merajut sebuah cerita bersama (Dewi et al., 2017; Fitry et al., 2019; Oktivianto et al., 2018). Melalui metode pembelajaran bermain peran, anak dilatih untuk mengungkapkan ide, harapan, dan keinginan mereka sesuai imajinasi dengan batasan cerita atau peran yang diberikan (Ananda, 2018; Fatimah, 2015; Kristin, 2018). Metode bermain peran juga memberikan suasana baru bagi anak didik dalam proses pembelajaran yang dilakukan dalam suasana bermain tanpa terbebani oleh tugas perkembangannya. Kelebihan bermain peran menjadikan suasana suatu pembelajaran akan lebih menyenangkan sebab bermain peran dapat membantu memecahkan permasalahan sebelumnya bersifat abstrak menjadi masalah konkret setelah diperankan, melalui bermain peran ini mengajarkan berbagai ketrampilan seperti bersosialisasi, spontanitas dan kreativitas dengan cara memerankan suatu peran yang nyata dalam kehidupan sehari-hari siswa (Kristin, 2018; Oktivianto et al., 2018; Yulianto et al., 2020).

Penelitian ini didukung beberapa penelitian sebelumnya yaitu, pertama penelitian yang dilakukan oleh (Labudasari \& Rochmah, 2018), yang mendapatkan hasil penelitian bahwa gerakan literasi berpengaruh terhadap karakter mandiri siswa sekolah dasar. 
Kedua, penelitian yang dilakukan oleh (Morelent \& Syofiani, 2018), yang mendapatkan hasil penelitian bahwa penerapan kurikulum 2013 berpengaruh terhadap pembentukan karakter siswa sekolah dasar. Ketiga, penelitian yang dilakukan oleh (Rosnawati et al., 2015), yang mendapatkan hasil penelitian bahwa model pembelajaran berbasis masalah bermain peran dapat meningkatkan rasa cinta tanah air siswa sekolah dasar. Implikasi penelitian ini berdampak pada karakter siswa yang semakin baik dan kegiatan belajar menjadi lebih aktif karena siswa menyukai pembelajaran Bahasa Indonesia melalui bermain peran karena menciptakan suasana yang menyenangkan.

\section{Simpulan}

Berdasarkan hasil hasil dan pembahasan yang diperoleh dapat disimpulkan bahwa melalui permaianan bermain peran terdapat nilai-nilai karakter yang terintegrasi didalamnya. Implikasi penelitian ini berdampak pada karakter siswa yang semakin baik dan kegiatan belajar menjadi lebih aktif karena siswa menyukai pembelajaran Bahasa Indonesia melalui bermain peran karena menciptakan suasana yang menyenangkan.

\section{Daftar Pustaka}

Ananda, R. (2018). Peningkatan Pembelajaran PKN Dengan Penerapan Metode RolePlaying Siswa Kelas II SDN 003 Bangkinang Kota. Jurnal Basicedu (Research \& Learning in Elementary Education), 2(1), 33-34. https://doi.org/10.31004/basicedu.v2i1.119

Ananda, R., \& Fadhilaturrahmi, F. (2018). Analisis Kemampuan Guru Sekolah Dasar Dalam Implementasi Pembelajaran Tematik Di SD. Jurnal Basicedu, 2(2), 11-21. https://doi.org/10.31004/basicedu.v2i2.42

Arwanda, P., Irianto, S., \& Andriani, A. (2020). Pengembangan Media Pembelajaran Articulate Storyline Kurikulum 2013 Berbasis Kompetensi Peserta Didik Abad 21 Tema 7 Kelas IV Sekolah Dasar. Al-Madrasah: Jurnal Pendidikan Madrasah Ibtidaiyah. https://doi.org/10.35931/am.v4i2.331

Astuti, A. P. (2016). Pengembangan Instrumen Penilaian Kompetensi Membaca Pada Mata Pelajaran Bahasa Indonesia Kelas VII Berbasis Quipper School. Jinop (Jurnal Inovasi Pembelajaran), 2(2), 334-350. https://doi.org/10.22219/jinop.v2i2.3635

Budi Febriyanto. (2019). Metode Cerita Berantai Untuk Meningkatkan Keterampilan Berbicara Siswa Pada Pembelajaran Bahasa Indonesia. Jurnal Cakrawala Pendas, 5(2), 40-44. https://doi.org/10.31949/jcp.v5i2.1388

Dardiri, A., Mujiyono, M., \& Ichwanto, M. A. (2017). Analisis Hasil Uji Kompetensi Guru Sekolah Menengah Kejuran Bidang Keahlian Teknik Bangunan. Teknologi Dan Kejuruan: Jurnal Teknologi, Kejuruan, Dan Pengajarannya, 40(2), 193-203. https://doi.org/10.17977/um031v40i22017p193

Dewi, T. R., Tegeh, I. M., \& Suarjana, I. M. (2017). Pengaruh Model Pembelajaran Kooperatif Tipe Role Playing Terhadap Hasil Belajar IPS Siswa Kelas V Gusus III Kecamatan Seririt Tahun Pelajaran 2016/2017. Mimbar PGSD Undiksha, 5(2), 110. https://doi.org/10.23887/jjpgsd.v5i2.10874

Dharmawan, D. W., Suarjana, I. M., \& Wibawa, I. M. C. (2014). Pengaruh Model Pembelajaran Role Playing Terhadap Keterampilan Berbicara Bahasa Indonesia Kelas V. Mimbar PGSD Undiksha, 2(1). https://doi.org/10.23887/jjpgsd.v2i1.3113

Fatimah, D. (2015). Pengembangan Model Bimbingan Kelompok Dengan Teknik Role Playing Untuk Mengembangkan Kepercayaan Diri Siswa. Jurnal Bimbingan Konseling, 4(1), 23-29. https://doi.org/10.15294/jubk.v4i1.6871 
Fitry, T., Maizora, S., \& Rusdi. (2019). Efektivitas Model Pembelajaran Role Playing Ditinjau Dari Hasil Belajar Matematika Siswa Smp Negeri 21 Kota Bengkulu. Jurnal Penelitian Pembelajaran Matematika Sekolah (JP2MS), 3(1), 6-12. https://doi.org/10.33369/jp2ms.3.1.6-12

Indriani, A. (2015). Penerapan Pembelajaran Tematik Kurikulum 2013 oleh Guru SD/MI di Desa Klepek Kecamatan Sukosewu Kabupaten Bojonegoro Semester Gasal Tahun Ajaran 2014/2015. Jurnal Varidika, 27(1), 43-49. https://doi.org/10.23917/varidika.v27i1.738

Indriyani, V., Zaim, M., Atmazaki, A., \& Ramadhan, S. (2019). Literasi Baca Tulis Dan Inovasi Kurikulum Bahasa. KEMBARA: Jurnal Keilmuan Bahasa, Sastra, Dan Pengajarannya, 5(1), 108. https://doi.org/10.22219/kembara.vol5.no1.108-118

Kristin, F. (2018). Meta-Analisis Pengaruh Model Pembelajaran Role Playing Terhadap Hasil Belajar Ips. Refleksi Edukatika: Jurnal IImiah Kependidikan, 8(2). https://doi.org/10.24176/re.v8i2.2356

Kurniasari, F. (2017). Implementasi Pendekatan Saintifik Pada Penugasan Aktivitas Di Buku Teks Bahasa Indonesia Kelas VII SMP Berdasarkan Kurikulum 2013. Jurnal Pendidikan Edutama, 4(1), 9-26. https://doi.org/10.30734/jpe.v4i1.44

Labudasari, E., \& Rochmah, E. (2018). Pengaruh Gerakan Literasi Sekolah Terhadap Karakter Mandiri Siswa Di SDN Kanggraksan Cirebon. Premiere Educandum: Jurnal Pendidikan Dasar Dan Pembelajaran, 9(1), 57-63. https://doi.org/10.25273/pe.v9i1.4254

Liu, K. (2019). Mengembangkan Keterampilan Membaca Kritis melalui Analisis Gaya di Kelas Bahasa Inggris Perguruan Tinggi Terintegrasi. Teori Dan Praktek Dalam Studi Bahasa, 9(3), 341-346. https://doi.org/10.17507/tpls.0903.13

Maulida, M., Wati, M., \& An'nur, S. (2015). Pengembangan Bahan Ajar Berbasis Pendidikan Karakter Dalam Mendukung Implementasi Kurikulum 2013. Berkala Ilmiah Pendidikan Fisika, 3(1), 11-19. https://doi.org/10.20527/bipf.v3i1.760

Morelent, Y., \& Syofiani. (2018). Pengaruh Penerapan Kurikulum 2013 Terhadap Pembentukan Karakter Siswa Sekolah Dasar Negeri 05 Percobaan Pintu Kabun Bukittinggi. Jurnal Penelitian Bahasa Dan Sastra Indonesia, 1(2), 141-152. https://doi.org/10.22202/jg.2015.v1i2.1234

Musaffak. (2014). Peningkatan Kemampuan Menulis Makalah Mahasiswa Pengambil Matakuliah Bahasa Indonesia Keilmuan Jurusan Pendidikan Bahasa Inggris FKIP UMM Semester II 2012 Dengan Strategi Peta Pikiran. Jurnal Pendidikan Humaniora, 1(4). https://doi.org/10.17977/jph.v1i4.4145

Oktivianto, O. I., Hudaidah, H., \& Alian, A. (2018). Pengaruh Implementasi Model Pembelajaran Role Playing dengan Media Film terhadap Motivasi Belajar Peserta Didik dalam Pelajaran Sejarah Materi Perang Palembang Kelas X di SMA Srijaya Negara Palembang. Jurnal Pendidikan (Teori Dan Praktik), 3(2), 113. https://doi.org/10.26740/jp.v3n2.p113-118

Puspidalia, Y. S. (2012). Problematika Pembelajaran Bahasa Indonesia Di MI/SD Dan Alternatif Pemecahannya. Cendekia: Jurnal Kependidikan Dan Kemasyarakatan, 10(1). https://doi.org/10.21154/cendekia.v10i1.406

Raditya, A., \& Iskandar, R. S. F. (2020). Analisis Soal PLSV pada Buku Ajar Matematika dari Kurikulum 1994 hingga Kurikulum 2013. Phenomenon: Jurnal Pendidikan MIPA, 9(2), 232-145. https://doi.org/10.21580/phen.2019.9.2.4066

Ramadan, S., \& Mulyat, Y. (2020). Makna Kata Dalam Bahasa Indonesia (Salah Kaprah Dan Upaya Perbaikannya). Ranah: Jurnal Kajian Bahasa, 9(1), 90-105. 
https://doi.org/10.26499/rnh.v9i1.1036

Ramadhanti, D. (2015). Strategi Penggunaan Kosakata Dan Tata Bahasa Dalam Berita Harian Umum Independen Singgalang. Jurnal Gramatika: Jurnal Penelitian Bahasa Dan Sastra Indonesia, 1(1), 89-99. https://doi.org/10.22202/jg.2015.v1i1.1160

Rosnawati, Atmaja, H. ., \& Suhandini, P. (2015). Pengembangan Model Pembelajaran Berbasis Masalah Bermain Peran Untuk Peningkatkan Rasa Cinta Tanah Air Siswa Kelas V Pada Materi Proklamasi Kemerdekaan. Journal of Primary Education, 4(2), 147-151. https://doi.org/10.15294/jpe.v4i2.10977

Shafa. (2014). Karakteristik Proses Pembelajaran Kurikulum 2013. Jurnal Dinamika IImu, 14(1), 81-96. https://doi.org/10.21093/di.v14i1.9

Sufanti, M., Hakim, L., \& Luckiyanti, R. (2017). Tingkat Kesulitan Dan Daya Beda Soal Tes Sumatif Bahasa Indonesia Berdasarkan Kurikulum 2013 SMP. Kajian Linguistik Dan Sastra, 26(2). https://doi.org/10.23917/kls.v26i2.4112

Tisnasari, S. (2017). Analisis Kesalahan Bahasa Pada Bangun Dan Perpaduan Leksem Bahasa Indonesia. Jurnal Handayani (JH), 7(1), 28-37. https://doi.org/10.24114/jh.v7i1.6572

Wahyuni, R., Utami, C., \& Husna, N. (2016). Pengaruh Model Role Playing Terhadap Kemampuan Komunikasi Matematis Siswa Pada Materi Fungsi Komposisi Kelas XI Sma Negeri 6 Singkawang. JPMI (Jurnal Pendidikan Matematika Indonesia), 1(2), 81. https://doi.org/10.26737/jpmi.v1i2.87

Widiatmaka, P. (2016). Kendala Pendidikan Kewarganegaraan dalam membangun karakter peserta didik di dalam proses pembelajaran. Jurnal Civics: Media Kajian Kewarganegaraan, 13(2), 188-198. https://doi.org/10.21831/civics.v13i2.12743

Yulia, D. S. F., Wahjoedi, W., \& Sapto, A. (2019). Pengaruh Metode Pembelajaran SQ3R Terhadap Hasil Belajar Bahasa Indonesia. Jurnal Pendidikan, 4(6). https://doi.org/10.17977/jptpp.v4i6.12537

Yulianto, A., Nopitasari, D., Qolbi, I. P., \& Aprilia, R. (2020). Pengaruh Model Role Playing Terhadap Kepercayaan Diri Siswa Pada Pembelajaran Matematika SMP. Jurnal Studi Guru Dan Pembelajaran, 3(1), 97-102. https://doi.org/10.30605/jsgp.3.1.2020.173 